\title{
The Effects of Agricultural Wastes on Degradation of PAHs and Abundance of Ammonia-Oxidizing Bacteria and Archaea in Soils
}

\author{
Xuemei $\mathrm{Han}^{1,2, \star}$, Chen Cheng ${ }^{1}$, Qingxia Duan ${ }^{1}$, Hui Wang ${ }^{1}$, Xiwei $\mathrm{Li}^{1}$, Donghao Wei ${ }^{1}$, Rui Zhang ${ }^{1}$ and Helian $\mathrm{Li}^{1}$ \\ ${ }^{1}$ School of Resources and Environment, University of Jinan, Jinan 250022, China \\ ${ }^{2}$ Shandong Provincial Engineering Technology Research Center for Ecological Carbon Sink and Capture Utilization, Jinan 250022, China
}

\begin{abstract}
The effects of agricultural wastes on degradation of polycyclic aromatic hydrocarbons(PAHs) and abundance of ammonia-oxidizing archaea (AOA) and ammonia-oxidizing bacteria (AOB) in PAH-polluted soils were determined by liquid chromatography and real-time quantitative PCR. The results showed that addition of agricultural wastes didn't improve the degradation of PAHs, in the contrary, the degradation of PAHs decreased in the soil added with wheat straw. And the degradation rate of PAHs decreased with increased molecular weight of PAHs. Furthermore, the abundance of AOA and AOB was enhanced in PAH-polluted soils after adding agricultural wastes, the content of pyrene and benzo[a]pyrene has significant negative correlation with the abundance of AOA. These results suggested that the degradation of PAHs can not be promoted through applying agricultural wastes into the soils freshly polluted by PAHs. Pyrene and benzo[a]pyrene would reduce the abundance of AOA, while addition of agricultural wastes could improve the ammonia oxidation function in PAH-polluted soils. This study provided some insights for the remediation and risk assessment of PAH-polluted soils.
\end{abstract}

\section{Introduction}

Polycyclic aromatic hydrocarbons (PAHs) are ubiquitous and refractory persistant organic pollutants (POPs) in environments [1]. They potentially threaten to human health and ecosystem security due to the properties of carcinogenesis, teratogenesis and mutagenesis and high bioaccumulation through the food chain [2-4]. With the fast pace of industrialization especially petrochemical and transportation industry, many farmlands and other soils are becoming heavily polluted by PAHs $[5,6]$. Therefore, economic and effective remediation techniques for PAH-polluted soils are widely concerned in recent years [7].

Biostimulation strategy, which is cost-effective and would not cause secondary pollution compared to regular chemical and physical process, becomes a promising option for removal of organic pollutants in soil [8]. Stimulating the growth of existing bacteria involved in degradation of PAHs through adding agricultural wastes as nutritious sources may be the easiest way to dissipate the PAHs in soil. However, it is not clear how the additional agricultural wastes affect microbial degradation of PAHs and the important indigenous functional bacteria such as ammonia-oxidizing archaea, (AOA) and ammonia-oxidizing bacteria (AOB).

In this study, three agricultural wastes were collected and separately added into PAH-polluted soil microcosms. The disperse of added PAHs and abundance of AOA and AOB during the whole incubation period were measured. The results is expected to give some insights to remediate the PAH-polluted soils and assess their ecological health risks.

\section{Materials and methods}

\subsection{Materials}

The sampling site was located in a forest of university of Jinan $\left(36^{\circ} 36^{\prime} \mathrm{N}, 116^{\circ} 57^{\prime} \mathrm{E}\right)$, where has a continental monsoon climate. Soils were collected from the top 10 $\mathrm{cm}$ of the profile. soils were mixed and homogenized thoroughly after being sieved through $2-\mathrm{mm}$ mesh. The physiochemical properties of mixed soils were measured using the standard methods recommended by the Soil Science Society of China [9]. The results were as following: moisture content was $12.69 \%$; $\mathrm{pH}$ was 8.12 ; the contents of total nitrogen, organic carbon and total phosphorus were $1.02,16.76$ and $0.945 \mathrm{~g} \mathrm{~kg}^{-1}$ dry soil, respectively. The basic properties of three agricultural wastes including cow manure (CM), wheat stalk (WS) and mushroom cultivation substrate waste (MCSW) were shown in table 1 .

Table 1. Content of total nitrogen (TN), total carbon (TC), total sulfur (TS) in agricultural wastes.

\begin{tabular}{|c|c|c|c|}
\hline $\begin{array}{c}\text { Agricultural } \\
\text { wastes }\end{array}$ & TN (\%) & TC (\%) & TS (\%) \\
\hline CM & $1.79 \pm 0.01 \mathrm{~b}$ & $27.40 \pm 0.01 \mathrm{c}$ & $0.91 \pm 0.03 \mathrm{a}$ \\
\hline $\mathrm{WS}$ & $0.85 \pm 0.01 \mathrm{c}$ & $36.72 \pm 0.15 \mathrm{a}$ & $0.61 \pm 0.06 \mathrm{~b}$ \\
\hline MCSW & $2.52 \pm 0.00 \mathrm{a}$ & $28.10 \pm 0.05 \mathrm{~b}$ & $0.49 \pm 0.01 \mathrm{c}$ \\
\hline
\end{tabular}

Note: Different letters in the same column indicate significant differences $(P<0.01)$ between different agricultural wastes.

\subsection{Experiment design}

The mixture of phenanthrene, pyrene and benzo[a]pyrene dissolved in acetone was added into the collected soils. Then the soils were placed in a fume hood overnight until acetone completely evaporated. After that, the soils were used to set up the microcosms. The soil microcosms added with CM, WS and MCSW were named treatment $\mathrm{CM}$, treatment WS and treatment MCSW, respectively. The soil microcosm without input of agricultural wastes was as a control. The added agricultural wastes were airdried and crushed by a grinder. The content of each 
added agricultural waste was $62.5 \mathrm{~g} \mathrm{~kg}^{-1}$ dry soil. Three replicates were performed for each treatment. The microcosm soils were incubated in darkness at $28{ }^{\circ} \mathrm{C}$ with $80 \%$ relative humidity for 135 days. About ten grams of soil samples were taken on day 15, 30, 55, 90 and 135 from each tray to determine the content of PAHs and abundance of AOA and AOB.

\subsection{Measurement methods}

\subsubsection{Measurement of PAHs content}

The PAHs in soil were extracted using ultrasonic extraction method recommended by the USEPA [10]. Briefly, $1 \mathrm{~g}$ of freeze-dried soil after being grounded and screened through 100-mesh sifter was extracted by $30 \mathrm{ml}$ of dichloromethane-hexane $(1: 1, \mathrm{v}: \mathrm{v})$ in an ultrasonic cleaner for three times. After being centrifugated, the supernatant from the same soil was mixed and concentrated through rotary evaporation. Then the supernatant continued to be concentrated to $1 \mathrm{ml}$ under a stream of $\mathrm{N}_{2}$ gas for measurement. The content of residual PAHs was determined using a liquid chromatograph (UltiMate 3000, Dionex) with ultraviolet detector. The maximum absorption wavelength was 254 $\mathrm{nm}$. The chromatographic column was $2.5 \mathrm{~cm} \times 4.6 \mathrm{~mm}$ and particle size was $5 \mu \mathrm{m}$. Acetonitrile-water (9:1, v:v) with a flow rate of $1 \mathrm{ml} \mathrm{min}^{-1}$ was used as the mobile phase. The column temperature was set at $30^{\circ} \mathrm{C}$.

\subsubsection{Measurement of $A O A$ and $A O B$ abundance}

Total microbial DNA was extracted from $0.25 \mathrm{~g}$ of soil with the MoBio PowerSoil DNA Isolation Kit according to the manufacturer's instruction. The extracted DNA was diluted 10 -folds and stored at $-20^{\circ} \mathrm{C}$.

The bacterial and archaeal $a m o A$ gene were amplified using an ABI 7500 thermocycler. The $20 \mu \mathrm{L}$ of PCR reaction buffer consisted of $2 \mu \mathrm{L}$ of template DNA, 0.5 $\mu \mathrm{L}$ of each primer $(10 \mu \mathrm{M}), 10 \mu \mathrm{L}$ of $2 \times$ TaKaRa SYBR Premix Ex Taq ${ }^{\mathrm{TM}}$ and $7 \mu \mathrm{L}$ of sterile water. The primer pairs and PCR reaction conditions are listed in table 2 . Standard curves for qPCR experiments were constructed according to the methods described by Lillis et al. [11]. Briefly, the genes of bacterial and archaeal amoA were amplified, respectively. The purified PCR products were purified with a Promega gel purification kit and cloned with the Promega pGEM-T Easy Vector system. Plasmids of the positive clones from each target gene insert were confirmed through sequencing. The copy numbers of the plasmid DNA were calculated according to their concentrations. The 10 -fold serial dilutions of each gene were used to construct the standard curve.
Table 2. Primer sets and thermal profiles used in the qPCR assays.

\begin{tabular}{|c|c|c|c|}
\hline $\begin{array}{l}\text { Target } \\
\text { gene }\end{array}$ & $\begin{array}{c}\text { Primer } \\
\text { set }\end{array}$ & Sequence $\left(5^{\prime}-3^{\prime}\right)$ & $\begin{array}{l}\text { Thermal } \\
\text { profile }\end{array}$ \\
\hline \multirow{2}{*}{$\begin{array}{c}\text { Bacterial } \\
\text { amoA }\end{array}$} & $\begin{array}{c}\text { amoA- } \\
1 \mathrm{~F}\end{array}$ & $\begin{array}{l}\text { GGGGTTTCTACT } \\
\text { GGTGGT }\end{array}$ & \multirow{2}{*}{$\begin{array}{l}95^{\circ} \mathrm{C} 30 \mathrm{~s} ; \\
95^{\circ} \mathrm{C} 10 \mathrm{~s} \text {, } \\
58^{\circ} \mathrm{C} 30 \mathrm{~s} \text {, } \\
72^{\circ} \mathrm{C} 1 \mathrm{~min} \\
\text { (plate read) } \\
\text { (35cycles); } \\
72^{\circ} \mathrm{C} 1 \mathrm{~min}\end{array}$} \\
\hline & $\begin{array}{l}a m o A- \\
2 \mathrm{R}\end{array}$ & $\begin{array}{l}\text { CCCCTCKGSAAA } \\
\text { GCCTTCTTC }\end{array}$ & \\
\hline \multirow{2}{*}{$\begin{array}{c}\text { Archaeal } \\
\text { amoA }\end{array}$} & $\begin{array}{c}\text { Arch- } \\
\text { amoA } \\
\text { F }\end{array}$ & $\begin{array}{c}\text { STAATGGTCTGGC } \\
\text { TTAGACG }\end{array}$ & \multirow{2}{*}{$\begin{array}{c}95^{\circ} \mathrm{C} 30 \mathrm{~s} ; \\
95^{\circ} \mathrm{C} 10 \mathrm{~s} \text {, } \\
55^{\circ} \mathrm{C} 30 \mathrm{~s} \text {, } \\
72^{\circ} \mathrm{C} 1 \mathrm{~min} \\
\text { (plate read) } \\
(35 \text { cycles); } \\
72^{\circ} \mathrm{C} 1 \mathrm{~min}\end{array}$} \\
\hline & $\begin{array}{c}\text { Arch- } \\
\text { amoA } \\
\text { R }\end{array}$ & $\begin{array}{c}\text { GCGGCCATCCATC } \\
\text { TGTATGT }\end{array}$ & \\
\hline
\end{tabular}

\subsection{Statistical analyses}

The gene abundance were log transformed before performing statistical analysis. One-way ANOVA based on Fisher LSD test was processed to examine the differences in content of residual PAHs, abundance of detected genes between different treatments at the same incubation time. Correlation analysis between content of residual PAHs and abundance of $\mathrm{AOA}$ and $\mathrm{AOB}$ was performed. The one-way ANOVA and correlation analyses were conducted using SPSS 17.0. Figures were drawn using OriginPro 7.5.

\section{Results and discussion}

\subsection{Content of the residual PAHs in different treaments}

The initial contents of phenanthrene, pyrene and benzo[a]pyrene were $5.28 \mathrm{mg} / \mathrm{kg}, 5.59 \mathrm{mg} / \mathrm{kg}$ and 5.8 $\mathrm{mg} / \mathrm{kg}$, respectively. The contents of residual PAHs in soils at day $15,30,55,90$ and 135 after adding various agricultural wastes are illustrated in Figure 1. Addition of agricultural wastes did not enhance the dissipation of PAHs compared with the control. In the contrary, contents of remaining phenanthrene at days 15 and 30 , pyrene during the whole incubation period, and benzo[a]pyrene since day 55 were higher in treatment WS than in other treatments and the control. It might attributed to the high content of organic matter in WS. Although it was considered that addition of agricultural wastes could provide more substrates for native microbial comunity, it was well known that organic matter could absorbed PAHs which might be the key factor impeding microbial degradation of PAHs [12]. In addition, the entered agricultural wastes were more readily usable organic substrates for native microbial community than PAHs in soil, which might lead to less microbial degradation of PAHs.

It is commonly acknowledged that microbial degradation of PAHs was subject to their availability for 
involved microbial populations [12]. Low molecular weight (LMW) PAHs had higher aqueous solubility and bioavailability, thus were more easily dissipated than high molecular weight (HMW) PAHs [2]. In fact, it was obvious that degradation of PAHs decreased with increasing number of aromatic rings in this study. At the end of incubation, removal rate of phenanthrene, pyrene and benzo[a]pyrene reached $95.49 \% \sim 96.21 \%, 92.2 \% \sim$ $97.22 \%$ and $58.21 \% \sim 90.53 \%$, respectively.
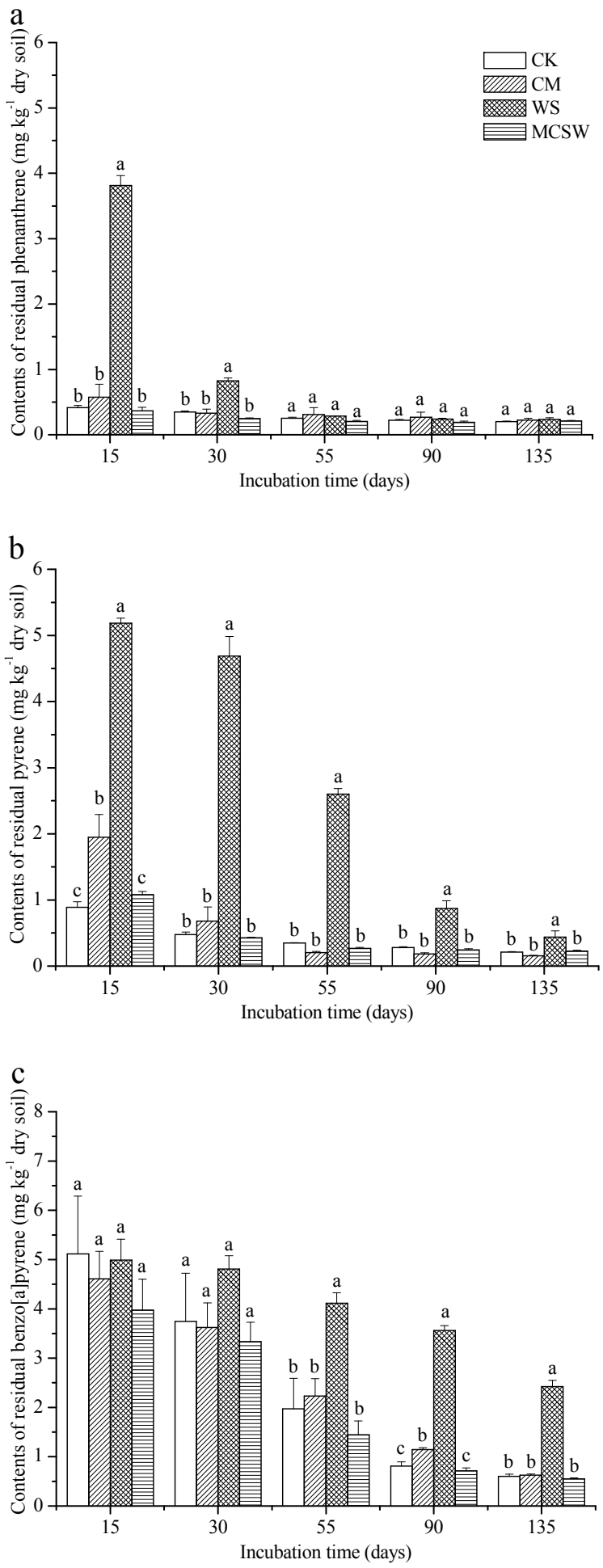

Figure 1. The content of soil PAHs in microcosms during the incubation period. Abbreviations represent the control (CK) and the soils treated by cow manure (CM) wheat stalk (WS), and mushroom cultivation substrate waste (MCSW) respectively. Error bars indicated the SD/2 of three replicates. Different letters indicate significant differences $(P<0.05)$ of residual PAHs content between different treatments at same sampling time.

\subsection{Abundance of $A O A$ and $A O B$ in different treatments}

Abundance of AOA in treatments $\mathrm{CM}$ and MCSW was significantly higher than that in the control during the whole incubation period with an exception of treatment MCSW at day 30 (Figure 2). AOB was more abundant in all microcosms treated by various agricultural wastes than the control during the entire cultivation time. These results indicated that input of carbon sources could enhance growth of AOA and AOB. The ratios of AOA and $\mathrm{AOB}$ abundance ranged from 0.98 to 12.53 for soils treated with agricultural wastes, compared with the ratios between 19.55 and 39.68 for the control. The lower ratios of $\mathrm{AOB}$ and $\mathrm{AOB}$ in treatments with agricultural wastes implied that added organic matter could stimulate the growth of AOB more effectively compared to the growth of AOA. It was consistent with some studies that found the better tolerance of $\mathrm{AOA}$ than $\mathrm{AOB}$ in relative oligotrophic conditions [13, 14].
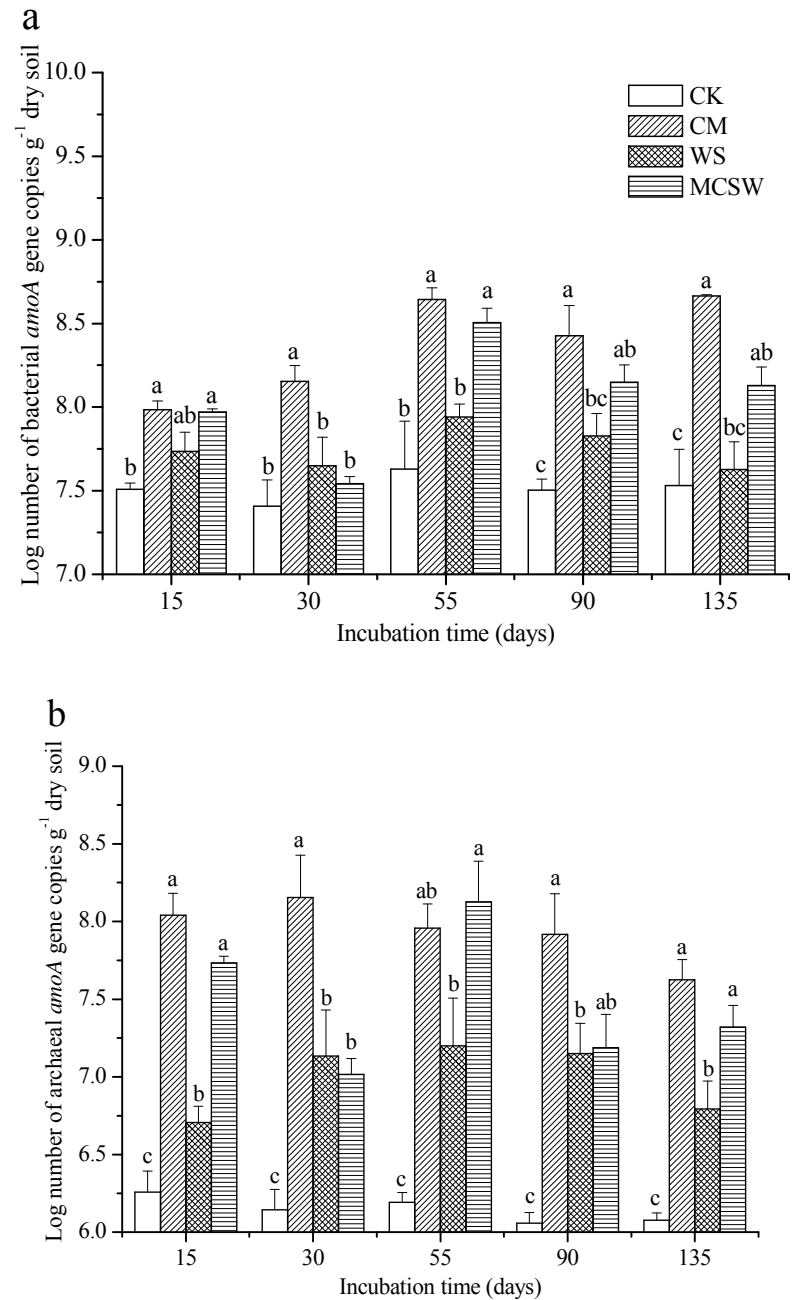


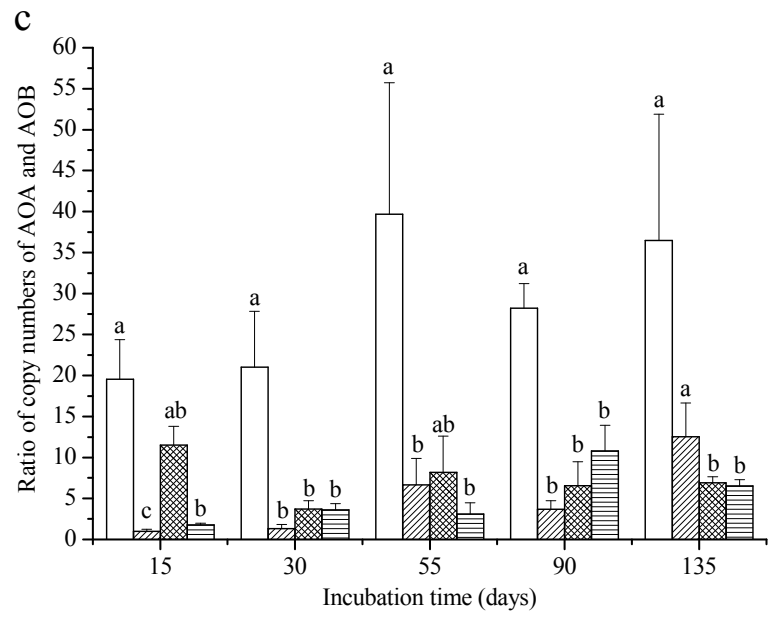

Figure 2. The abundance of $\mathrm{AOA}$ and $\mathrm{AOB}$ and their ratios in microcosms during the incubation period. Meanings of abbreviations and error bars refer to figure 1. Different letters indicate significant differences $(P<0.05)$ in AOA abundance, $\mathrm{AOB}$ abundance or ratios of $\mathrm{AOA}$ and $\mathrm{AOB}$ abundance between different treatments at same sampling time.

\subsection{Correlation between residual PAHs and AOA and $A O B$}

Correlation between content of residual PAHs and abundance of AOA and AOB were analyzed. There was no significant relationship between content of PAHs and abundance of AOA, while abundance of AOB was negatively correlated with content of pyrene and benzo[a]pyrene residues in soils (Table 3). It indicated that AOA could be inhibited by PAHs especially HMW PAHs in soils.

Table 3. The correlation coefficients between PAHs content and abundance of AOA or AOB.

\begin{tabular}{|c|c|c|c|}
\hline Gene & Phenanthrene & Pyrene & Benzo[a]pyrene \\
\hline AOA & -0.151 & $\mathbf{- 0 . 2 8 0 *}$ & $\mathbf{- 0 . 3 6 9 * *}$ \\
\hline AOB & -0.113 & -0.077 & -0.059 \\
\hline
\end{tabular}

Note: Significant correlations are highlighted in bold. * and ** represent the significance levels of $P<0.05$ and $P$ $<0.01$, respectively.

\section{Conclusions}

In this study, addition of agricultural wastes did not improve the elimination of PAHs in soils. In the contrary, WS impeded the dissipation of PAHs. LMW PAHs were degraded more easily and faster than HMW PAHs. Input of agricultural wastes could stimulate the growth of microbes involved in ammonia oxidation especially AOB. PAHs pollution had a negative effect on abundance of AOA.

\section{Acknowledgements}

This work was financially supported by the National Natural Science Foundation of China (41301567), Key Research and Development Program of Shandong Province (2015GSF117033), and Shandong Provincial Higher Educational Science and Technology Program (J12LC02).

\section{References}

[1] A.R. Johnsen, L.Y. Wick, H. Harms, Environ. Pollut. 133 (2005)

[2] R.H. Peng, A.S. Xiong, Y. Xue, X.Y. Fu, F. Gao, W. Zhao, Y.S. Tian, Q.H. Yao, FEMS Microbiol. Rev. 32 (2008)

[3] A.R. Johnsen, S. Schmidt, T.K. Hybholt, S. Henriksen, C.S. Jacobsen, O. Andersen, Appl. Environ. Microb. 73 (2007)

[4] M. Niepceron, F. Martin-Laurent, M. Crampon, F. Portet-Koltalo, M. Akpa-Vinceslas, M. Legras, D. Bru, F. Bureau, J. Bodilis, Environ. Pollut. 180 (2013)

[5] J. Baranieckaa, K. Pyrzyńska, M. Szewczyńska, M. Pośniak, E. Dobrzyńska, J. Hazard. Mater. 183 (2010)

[6] M.I. Bakker, U.B. Casado, J.W. Koerselman, J. Tolls, C. Kollöffel, Sci. Total Environ. 263 (2000)

[7] F. Musant, A. Galushko, J. Jacob, F. Widdel, M. Kube, R. Reinhardt, H. Wilkes, B. Schink, R. Rabus, Environ. Microbiol. 11 (2009)

[8] R. Canet, J.G. Birnstingl, D.G. Malcolm, J.M. Lopez-Real, A.J. Beck, Bioresource Technol. 76 (2001)

[9] R.K. Lu, Analysis methods of soil agrichemistry (China Agricultural Science and Technology Press, Beijing, 1999)

[10] USEPA, Method 3550C, Test methods for evaluating solid waste. EPA SW-846 (US Government Print Office, Washington, 2000)

[11]L. Lillis, N. Clipson, E. Doyle, FEMS Microbiol. Ecol. 73 (2010)

[12]T. Kobayashi, Y. Murai, K. Tatsumi, Y. Iimura. Sci. Total Environ. 407 (2009)

[13] A. Sims, Y. Zhang, S. Gajaraj, P.B. Brown, Z. Hu, Water Res. 47 (2013)

[14]E. Wessén, S. Hallin, Ecol. Indic. 11 (2011) 